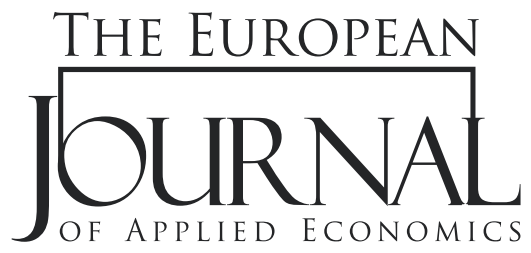

EJAE 2020, 17(1): 80 - 103

ISSN 2406-2588

UDK: 339.564(4-672EU)

338.121(4-672EU)

DOI: $10.5937 /$ EJAE17-23638

Original paper/Originalni naučni rad

\title{
HAVE EXPORT COMPOSITIONS INFLUENCED ECONOMIC GROWTH OF THE EUROPEAN UNION COUNTRIES IN CENTRAL AND EASTERN EUROPE?
}

\author{
Donny Tang \\ Economics Department, \\ Temple University, \\ Philadelphia, USA
}

\begin{abstract}
:
This study analyzes export composition effects on economic growth in the European Union (EU) countries of Central and Eastern Europe (CEE) during 1999-2016. The results confirm that the fuel and food exports have boosted growth after EU accession. As expected, agricultural exports have no effect on growth. Due to the different comparative advantages, the CEE countries have still relied on some raw material exports while developing manufactured exports. The results also indicate that the transportation equipment, textile, steel, and chemical exports have accelerated growth. This can be attributed to the economies of scale in production, given their greater access to EU markets.
\end{abstract}

Article info:

Received: October 17, 2019

Correction: November 16, 2019

Accepted: December 4, 2019

\section{Keywords:}

export composition, economic growth, economic integration.

JEL Codes:

F10, F14, F15, F43, O52

\section{INTRODUCTION}

The relationship between export and economic growth has been one of the most crucial issues in development economics literature. They found a positive export effect on economic growth in developing countries. However, most of them failed to distinguish between different types of exports and their respective effects on growth. The reason why this is important is that productivity and externality effects associated with exports are likely to be higher in the case of manufactured exports as opposed to primary exports (Greenaway, Morgan, and Wright, 1999). Given that export emphasis is shifting from primary to manufactured exports, developing countries can achieve higher economic growths in the long run. This paper examines whether export compositions have played a crucial role in determining economic growth in the European Union (EU) countries in Central and Eastern European (CEE) countries during 1999-2016. 
The disaggregated export composition analysis would provide valuable insights into the exportgrowth relationship since EU accession in 2004. The results would indicate whether manufactured export specialization would facilitate higher growth than raw material export specialization.

Most previous studies confirmed the contribution of exports to economic growth of the CEE countries during the transition period (Dawson and Hubbard, 2004). At the early stage of development, they still relied on labor-intensive and raw material products as their major export products to earn export revenues. During the 1990s, the massive inflows of foreign direct investments had helped these countries gain significant comparative advantages in manufactured exports (Zaghini, 2005). Specifically, the open trade policy facilitated their access to the advanced technologies of western EU countries (De Boyrie and Johns, 2013). More developed CEE countries allocated more resources toward high-technology manufactured exports to target western EU markets. The export diversification policy helped consolidate their market shares in these countries. As they achieved higher economic growth, they started to specialize in high-quality manufactured exports with comparative advantages (Naude, Bosker, and Matthee, 2010). The export specialization policy helped to expand their market shares in high-income countries. Since their EU accession, the CEE countries enjoyed economies of scale in production and marketing, as they had greater access to the entire EU markets. Their focus on high-quality manufactured exports made themselves more competitive in the EU countries (Kali, Mendez, and Reyes, 2007). Their strong export performance explained their sustainable high growth over the past two decades.

Some of the CEE countries had deepened their financial integration with western EU countries by joining the European Monetary Union (EMU) in 2008. The adoption of the euro, which eliminated exchange rate volatility, further boosted the trade flows between the CEE and the western EU countries. The deep CEE trade ties with more affluent trading partners accelerated their economic growth. It is noteworthy that the CEE countries with export compositions similar to that of western EU countries tended to achieve higher income convergence (De Benedictis and Tajoli, 2007b; De Benedictis and Tajoli, 2008). This can be attributed to the major shift in export composition from primary to manufactured exports. The resource allocation toward more productive export sectors helped these countries achieve better export performances. This in turn reduced their income gap with western EU countries. The emphasis on manufactured exports was very favorable for promoting their growth over the past decades (Balaguer and Cantavella-Jorda, 2004). Similar to the CEE countries, the developing eurozone countries further boosted their growth through increasing the share of high technology exports in total exports during 1988-2009. In general, market competition for high-technology products depends on quality rather than price. Their overall demand would remain very stable regardless of change in relative product prices (Wierts, Van Kerkhoff, and De Haan, 2014). The western EU countries have long served as major export markets for the CEE raw materials and manufactured exports. Their strong trade ties have facilitated the progress toward specialization in high-technology manufactured exports. An in-depth analysis of export composition pattern would suggest the best export-led growth policies for the CEE countries in the near future.

This is one of very few studies to examine the effect of CEE export compositions on economic growth. The CEE countries have been accelerated their economic growth through export promotion policy since the early 1990s. More developed countries, such as Hungary and Poland, shifted their export emphasis from primary to manufactured exports since their EU accession. Those countries that mainly imported capital goods for producing consumer goods grew faster than those that only exported capital goods (Lewer and Van den Berg, 2003). Their change in the export composition pattern helped sustain their 
high economic growth for the past two decades. As some of these countries achieved middle-income status, they further diversified their export types to expand their export markets. While they allocated more resources to develop high-technology manufactured exports at the later stage of development, they also continued their raw material exports to earn stable amounts of export revenues, especially during the crisis period (Grancay, Grancay, and Dudas, 2015). To sustain high economic growth in the long run, the CEE countries would need to develop more effective export composition policies to boost their export competitiveness. In particular, they have to better coordinate industrial and trade policies for allocating resources in high-technology production innovation (Cuaresma and Worz, 2005). This study would suggest the appropriate export composition policies for maintaining high economic growth for CEE countries in the long run.

The remainder of this study is structured as follows: Section 2 provides a brief literature review on the impact of export on economic growth. It focuses on the importance of export diversification and specialization policy for growth in developing countries. Section 3 describes the empirical models for estimating the impact of export compositions on economic growth after EU accession. Section 4 presents the results and discusses their significance. The policy implications for long-term export policies to boost growth are discussed in section 5 . Section 6 concludes with a summary of the main results.

\section{LITERATURE REVIEW}

Most empirical studies confirm the positive export effect on economic growth in developing countries. They further examine the importance of export diversification in boosting growth. Developing countries can achieve higher growth through export diversification at the early stage of development (Naude, Bosker, and Matthee, 2010). To a certain extent, foreign direct investment inflows help these countries diversify their exports. Local companies can adopt foreign production technologies to improve the quality of their exports. High export diversification would make their economies better insulated against foreign economic shocks. It would help these countries to facilitate deeper industrialization process in the long run (Eicher and Kuenzel, 2016). As developing countries become middle-income countries, they gradually shift their emphasis toward export specialization to boost their export competitiveness (Naude and Rossouw, 2011). Nonetheless, some of these countries still maintain export diversification in both primary and manufactured export production. Even upper middle-income countries can achieve high growth through export diversification (Gozgor and Can, 2017). However, this may indicate slow adjustment in the industrialization process when high-technology manufactured export sectors appear rapidly but low-skilled manufactured export sectors still remain (Cadot, Carrere, and Strauss-Kahn, 2011). As a result, their overall economic growth rates would slow down. Developing countries must learn how to balance export diversification in primary and manufactured exports. They should allocate appropriate resources to improve their production efficiency in the long run.

Previous studies provide strong evidence for the role of export specialization in facilitating economic growth. As developing countries become middle-income countries, they can produce high value-added industrial goods for both local and foreign markets. They can accelerate their growth through export specialization in high-technology manufactured goods. Countries exporting goods with higher productivity levels would achieve higher growth than those with lower productivity levels. The production of manufactured exports is associated with higher productivity and externality effects (Greenaway, Morgan, and Wright, 1999). These exports can bring positive externalities, such as knowledge and technology spillovers, to developing countries improving their product innovation (Wierts, Van 
Kerkhoff, and De Haan, 2014). Thus, countries grow faster if they primarily import capital goods to produce consumer goods. In some cases, fuel, metals, and textile export specialization can lead to higher growth than primary, food, and machinery export specialization (Naude, Bosker, and Matthee, 2010). Further improvement in production efficiency would increase the competitiveness of fuel, metals, and textile exports. The capacity to produce more sophisticated goods would yield positive externalities that are highly conducive to growth (Hausmann, Hwang, and Rodrik, 2007). Exports of high-quality manufactured goods would help developing countries increase their export revenues which, in turn, would boost their growth.

Relevant studies argue that the growth effect of export specialization may vary depending on the prices of primary exports. If the prices of these exports remain stable, countries producing more sophisticated exports would achieve higher growth (Grancay, Grancay, and Dudas, 2015). Moreover, the product quality would affect economic growth. Compared to countries with an emphasis on lowquality exports, countries with an emphasis on high-quality exports would experience higher growth (Huchet-Bourdon, Le Mouel, and Vijil, 2018). Richer developing countries would need to focus on high-technology manufactured exports to maintain high growth. In other words, they have to shift from export diversification to export specialization as part of their long-term growth policy. Other studies point out that the income of trading partners may affect economic growth. Developing countries that mainly trade with developed countries would achieve higher growth, as they can benefit from technology transfer from these countries. More importantly, the skilled labor participation in high-technology export production would facilitate technological innovation in other types of exports (Kali, Mendez, and Reyes, 2007). Developing countries can quickly catch up with developed countries in product innovation through technology transfer.

Similar studies compare different growth effects between raw material exports and high-technology manufactured exports. In contrast to high-technology exports, raw material exports would result in lower growth among developing countries. In some cases, raw material exports may have no impact on growth at all (Poncet and De Waldemar, 2013). Developing countries should diversify their export composition to achieve sustainable higher growth (Murshed and Serino, 2011; Dreger and Herzer, 2013). While they often can boost their growth through shifting toward differentiated manufactured exports, they would need to continue to produce raw material exports for earning stable amount of export revenue. In general, global demand for raw material exports remains high because most of them are necessity products. Even major economic shocks would not substantially affect their overall demand. It is important for developing countries to better allocate resources for producing both raw materials and manufactured exports. Exposure to international competition would result in a more efficient use of production resources and boost their overall productivity (Cuaresma and Worz, 2005). For the past decades, most developing countries have substantially boosted their economic growth through adopting export-led growth policy. Given the positive relationship between export and growth, it is important to examine whether raw materials and manufactured exports have played a crucial role in promoting economic growth among the CEE countries. The results would suggest the appropriate amount of resource allocation for their production in the long run. 


\section{ECONOMETRIC SPECIFICATION}

\section{Estimation Model}

The empirical model examines whether export compositions have affected the CEE economic growth during the period 1999-2016. The regression equation, which includes various types of raw material and manufactured exports, is given as:

$$
\begin{aligned}
\log (\text { GDPGrowthit })=\alpha & +\beta_{1} \log \left(\text { Curact }_{i t}\right)+\beta_{2} \log \left(\text { Debt }_{i t}\right)+\beta_{3} \log \left(\text { Tconcen }_{i t}\right)+\beta_{4} \log \left(\text { FDI }_{i t}\right) \\
& +\beta_{5} \log \left(\text { Popgrow }_{i t}\right)+\beta_{6} \log \left(\text { Capform }_{i t}\right)+\beta_{7} \log \left(\text { School }_{i t}\right) \\
& +\beta_{8} \log \left(\text { Agric }_{i t}\right)+\beta_{9} \log \left(\text { Food }_{i t}\right)+\beta_{10} \log \left(\text { Fuel }_{i t}\right)+\beta_{11} \log \left(\text { Mach }_{i t}\right) \\
& +\beta_{12} \log \left(\text { Textil }_{i t}\right)+\beta_{13} \log \left(\text { Transp }_{i t}\right)+\beta_{14} \log \left(\text { Steelchem }_{i t}\right)+\varepsilon_{i t}
\end{aligned}
$$

where GDPGrowth it $_{\text {it }}$ the growth rate of real gross domestic product (GDP) per capita of the CEE country $i$ at year $t$ (1999-2016). All variables are measured in US dollars adjusted for inflation to the base year 2005. The CEE countries include Bulgaria, Croatia, Cyprus, the Czech Republic, Estonia, Hungary, Latvia, Lithuania, Malta, Poland, Romania, Slovakia, and Slovenia. In particular, Cyprus, the Czech Republic, Estonia, Hungary, Latvia, Lithuania, Malta, Poland, Slovakia, and Slovenia joined the EU in 2004. While Bulgaria and Romania joined the EU in 2007, Croatia followed suit in 2013. Only seven CEE countries have joined the EMU as they have fulfilled the convergence criteria for euro adoption. Slovenia first adopted the euro in 2007, whereas Cyprus and Malta adopted it in 2008. Subsequently, Slovakia and Estonia adopted it in 2009 and 2011, followed in suit by Latvia and Lithuania in 2014 and 2015 (European Commission, 2019). Due to the elimination of trade barriers, the EU has allowed the CEE countries to boost their trade flows with western EU countries. Moreover, the EMU that has facilitated the use of the euro in seven CEE countries has expanded their trade flows with eurozone countries. As expected, the EMU substantially promoted trade flows among eurozone countries during 2000-2013 (Mikaa and Zymekb, 2018). Since the eurozone and non-eurozone CEE countries have established closer trade ties with western EU countries, their inclusion in this study would provide more accurate analysis of the export composition effect on economic growth.

The main variables of interest are the export composition variables - raw materials and manufactured export variables. The raw material export variables (Agric, Food, and Fuel) are the total values of agricultural exports, food exports, and fuel exports divided by the CEE GDP. To adopt export-led growth policy, developing countries always depend on raw material products as their main exports at the early stage of development. Dependence on raw material exports would help boost growth if these exports would remain in high demand (Naude, Bosker, and Matthee, 2010). The rising prices of these exports have made them to be one of the main growth determinants in developing countries for decades (Grancay, Grancay, and Dudas, 2015). On the contrary, previous studies argue that raw material exports have no impact on growth in the long run. There may be a positive relationship between raw material exports and economic growth. But this effect may not persist in the long run (Poncet and De Waldemar, 2013). Developing countries would not maintain sustainable high growth if they failed to develop high-technology manufactured industries (Murshed and Serino, 2011; Dreger and Herzer, 2013). In fact, raw material exports may have a negative effect on growth because a growing number of developing countries compete for the same export markets. To boost their export competitiveness, they need to emphasize export diversification in high-technology manufactured exports at the later stage of industrialization. Based on these arguments, the raw material export variable may have either positive or negative effect on the CEE economic growth. 
The other important export composition variables are the manufactured export variables. Mach, Textil, Transp, and Steelchem refer to the total values of machinery exports, textile exports, transportation equipment exports, and steel and chemical exports divided by the CEE GDP. In contrast to the raw material export variables, the manufactured export variables always have a positive effect on growth in developing countries. They can achieve higher growth if they specialize in new high-quality manufactured exports (Huchet-Bourdon, Le Mouel, and Vijil, 2018). Export composition has facilitated the better export performance of eurozone countries for the past two decades. In particular, they have accelerated their growth through increasing the share of high-technology exports in their total exports (Wierts, Van Kerkhoff, and De Haan, 2014). The reason is that high-technology exports tend to have higher productivity levels, which would increase profits for developing countries (Naude, Bosker, and Matthee, 2010). Moreover, these exports would yield positive externalities, such as knowledge and technology spillovers. More efficient resource allocations, along with higher productivity level and technological progress, would make these exports more competitive in global markets (Cuaresma and Worz, 2005). Developing countries would grow faster if they shifted from export diversification to export specialization policy at the later stage of development. In fact, the CEE countries have adopted export-oriented growth policies before joining the EU. They signed several free trade agreements to gain access to western EU markets during the 1990s. The EU has further boosted their trade flows because of the removal of non-tariff trade barriers. Some of the CEE countries have joined the EMU to deepen their trade ties with richer eurozone countries (Jagelka, 2013). The access to the larger export markets has allowed them to benefit from economies of scale in production of high-technology manufactured exports. The allocation of more resources to produce higher productivity exports, such as machinery and transportation equipment exports, would help accelerate their economic growth in the long run. Therefore, the manufactured export variable would have a positive effect on the CEE economic growth.

Another variable of interest is the trade concentration variable (Tconcen). The trade concentration variable is the Hirschman Herfindahl index, which measures the dispersion of trade value across an exporter's partners. A country with trade that is concentrated in a very few markets would have an index value close to one. Similarly, a country with a perfectly diversified trade portfolio would have an index value close to zero. Developing countries can achieve higher growth from trade concentration due to the benefit of economies of scale. This would allow them to allocate their major production resources for a few high value-added export products. The large-scale production would facilitate more foreign technology transfer and adoption. Their exports would become more competitive in high-income countries (Kali, Mendez, and Reyes, 2007). The CEE countries have showed high trade concentration since the 1990s. The EU accession has boosted their trade concentration in western EU countries because of the strong consumer demand for manufactured exports. The good export performance has been conducive to high economic growth. Therefore, the higher trade concentration variable would have a positive effect on the CEE economic growth.

Foreign direct investment is considered one of the main growth determinants for the CEE countries. The foreign direct investment variable (FDI) is equal to the FDI inflows divided by the CEE GDP. The local manufacturing industries would benefit from FDI inflows through technology and management skill transfer. The positive externalities can help accelerate their technological process and therefore raise productivity level. The export-oriented firms can further boost their export competitiveness (Sohinger, 2005). The CEE countries have received huge FDI inflows from western EU countries since the mid-1990s because they have very favorable investment environments for foreign investors. Most of these inflows have included the imports of high-technology product components. 
The local firms have adopted the latest foreign technologies to facilitate their product innovation. To some extent, they have accelerated their technological progress to produce more high value-added industrial goods. Better export performance has further boosted their economic growth (Jouini, 2015). The FDI variable would have positive effect on the CEE economic growth.

The other explanatory variable that can significantly affect growth is the current account variable (Curact). Curact is the current account balance which is equal to the sum of net exports of goods and services, net primary income, and net secondary income as a share of the CEE GDP. The current account deficit would incur heavy financial burden on interest repayment, which eventually would lead to major debt default in the CEE countries (Cuestas, 2013). Moreover, the persistent current account deficit would make their economies more volatile to external economic shocks. Therefore, current account deficit would have a negative effect on their economic growth. However, it may have a positive effect on their economic growth. Since EU accession, the CEE countries have received the higher level of foreign borrowing because of greater access to the larger EU financial markets. Their current account deficits have further increased (Slavov, 2009). EMU membership has deepened their stock market and banking sector integration with western EU countries. Greater access to massive foreign capital inflows has financed their growing consumption and investment (Herrmann and Winkler, 2009). To a certain extent, the larger current account deficits have sustained their high economic growth since EU accession. Therefore, the current account variable may have either a positive or negative effect on the CEE economic growth.

The public debt variable (Debt) is the total amount of public debt divided by the CEE GDP. An increase in debt level would have positive or negative effect on economic growth. The short-term debt effect on economic growth is positive. But the positive effect from short-term economic stimulus from more debt may decrease when the initial debt level is high. Eventually, the debt level would have negative effect on growth (Baum, Checherita-Westphal, and Rother, 2013; Eberhardta and Presbiteroc, 2015). More debt accumulation would have a very negative growth impact among countries with debt-toGDP ratios above 95 per cent. The increase in public debt, followed by the relaxation of fiscal austerity programs, may not boost economic growth in high indebted countries. In fact, it may increase their decline (Gomez-Puig and Sosvilla-Rivero, 2015). This is the case for the twelve eurozone countries with debt-to-GDP ratios of about 90-100 percent (Checherita-Westphal and Rother, 2012). High levels of debt in Greece, Italy, and Spain primarily triggered the eurozone debt crisis in 2010. They experienced very slow economic growth for several years after the crisis. Therefore, the public debt variable would have a negative effect on the CEE economic growth. It is noteworthy that most of the CEE countries have maintained very low public debt levels to avoid loan default. The moderate debt increase due to growing economic activities since EU accession has boosted their economic growth. Hence, the public debt variable may have positive effect on the CEE economic growth.

The three control variables are the population growth (Popgrow), capital formation (Capform), and education (School) variables. Popgrow is the annual population growth rate in the CEE countries. Population growth is considered a key measure for human capital. At the early stage of economic development, developing countries need a large number of jobs for economies of scale production. The labor productivity would increase as jobs have become more skillful in adopting the latest technologies. Hence, population growth has a positive effect on economic growth because of more efficient production processes (Grancay, Grancay, and Dudas, 2015). A more educated labor force and high population growth both have strong positive effects on growth (Naude, Bosker, and Matthee, 2010). Compared to other developing countries, the CEE countries have a very educated labor force for efficient production. 
They can facilitate more a efficient production of high-technology manufactured exports. Hence, the population growth variable would have a positive effect on the CEE economic growth.

The capital formation variable (Capform) refers to the gross capital formation as a share of the CEE GDP. It includes the expenditures on additions to fixed assets of the economy and net changes in inventory level as a share of GDP. Capital formation measures domestic investment. High domestic investment would boost economic growth in countries with high institutional quality (Dort, Meon, and Sekkat, 2014). Since EU accession, the CEE countries have substantially improved the quality of their investment environments for foreign investors. More importantly, lower labor costs within the CEE countries have helped reduce total production costs. The substantial increase in production activities has certainly boosted their economic growth. Therefore, the capital formation variable would have a positive effect on the CEE economic growth. Finally, the secondary school enrollment variable (School) is the proportion of the labor force that has secondary school education as a percentage of the total labor force in the CEE countries. It indicates the number of educated job positions available for complex productions. Secondary school enrollment is used in this study because complete data is available for all of the CEE countries. The more educated labor force would be highly favorable for research and development activities (Sterlacchini, 2008). The quick conversion of research innovations into commercial products would make CEE exports more competitive in western EU countries. Strong leadership in advanced technology would contribute to their sustainable higher economic growth in the long run. Hence, the secondary school enrollment variable would have a positive effect on the CEE economic growth.

The major variables included in equation (1) have been described in details. Table 7 reports summary statistics for the dependent and independent variables, including the instrumental variables.

\section{Two-Stage Least Squares and Generalized Method of Moments Estimations}

There may be an endogeneity problem in the FDI variable. It is possible that FDI inflows would boost economic growth due to their positive externalities. But countries with higher growth can better attract more FDI inflows as they are considered more profitable markets by foreign investors. They can tap consumer markets for their expensive imports. To address the endogeneity problem, this study would use the two-stage least squares (2SLS) method to re-estimate the endogenous variable, namely, the foreign direct investment variable (FDI). The instrumental variables (IV) would replace FDI. The research and development expenditure variable (Rdexp) and inflation rate variable (Inflat) are the IV for FDI. Rdexp is the research and development (R\&D) expenditures as a share of the CEE GDP. R\&D expenditures include current and capital expenditures (both public and private) on creative work undertaken to increase knowledge and the use of knowledge for new applications. Higher R\&D spending indicates the CEE determination to become research-intensive locations for foreign investors (Hubert and Pain, 2002). This would help attract more foreign direct investment in CEE countries. Hence, higher R\&D spending would boost foreign direct investment inflows into the CEE countries. Moreover, the inflation rate variable (Inflat) is the inflation rate of the CEE countries measured by the consumer price index. It reflects the annual percentage change in the cost of living of average consumers, i.e., for buying goods and services that may be fixed or changed at a specified interval (yearly). The higher inflation rate would substantially affect the total production costs for foreign investors as it would result in higher wage increases. Therefore, higher inflation rates would deter foreign direct investment inflows into the CEE countries. 
In addition to the 2SLS method, equation (1) is also re-estimated by the dynamic generalized method of moments (GMM) method to control for the biases related to endogeneity, omitted variables, and unobserved country fixed effects. It can also address the heteroscedasticity and serial correlation problem. The first difference procedure is chosen as the transformation method to remove the crosssection fixed effects. The two IV for the FDI variable in the 2SLS methods are included as the IV in the dynamic GMM method.

The dataset for this study was available at Mendeley data website. The details on statistical software and procedures to derive the results were provided in my dataset (Tang, 2019).

\section{Data Sources}

The World Bank's World Development Indicators database provides the data for the dependent variable (growth of real GDP per capita) and some of the independent variables (current account balance, foreign direct investment inflow, population growth, capital formation, and education). Trade concentration data are obtained from the World Bank's World Integrated Trade Solution database. The public debt data are available in the International Monetary Fund's Historical Public Debt database. All of the raw material and manufactured export data are taken from the Eurostat database.

\section{ESTIMATION RESULTS}

\section{Export Composition Effects on the CEE Economic Growth}

This study examines whether the export compositions have affected the economic growth in the CEE countries during 1999-2016. The EU and EMU have boosted the CEE export flows to the other member countries. To better assess the EU financial integration effect, the entire study period is divided into two subperiods for further analysis. The comparison of the two periods (1999-2003 and 2004-2016) would suggest whether the higher export flows triggered by the deeper financial integration have accelerated the CEE economic growth since EU accession in 2004. Moreover, the 2008 financial crisis and the 2010 eurozone debt crisis resulted in a drastic fall in consumer demand for the CEE exports to western EU countries. This led to their lower economic growth for several years after the crisis outbreak. Hence, this study would compare the pre-crisis and crisis periods (2004-2008 and 2009-2016) to determine whether the change in export flows due to the crisis outbreak has substantially affected the CEE economic growth during 2009-2016.

The main issue of this study is whether the export compositions have facilitated the higher CEE economic growth for the past two decades. To better analyze the disaggregated export effects, the estimations would be conducted for the raw material and manufactured export effects on growth respectively. The 2SLS and GMM estimation results for both types of exports are provided in Tables 1 and 4. The results for the raw material exports are given in Tables 2 and 5. The overall results indicate that the fuel exports have a strong positive impact on the CEE economic growth after the EU accession. As seen in Tables 4 and 5, the GMM coefficient on Fuel is positive and statistically significant at the 1 percent level for the entire period 1999-2016. Moreover, the subperiod results in Table 5 indicate that the size and statistical significance of the coefficient became larger in 2004-2016 than in 2009-2016. This suggests that the positive fuel effect on growth appeared to be stronger during the EU period 2004-2016. 
But this effect has somewhat declined due to the outbreak of the US financial crisis and the eurozone debt crisis in 2009-2016. In contrast to the strong fuel export effect, the food exports only have a positive effect on the CEE growth during the crisis period 2009-2016. The coefficient on Food is positive in 2004-2016 and 2009-2016, but only becomes statistically significant in the latter period. This result should be interpreted with caution. The positive food effect during 2009-2016 could be attributed to the crisis factor. To offset the drastic drop in the export demand, the CEE countries might have allocated main resources to produce necessity goods, such as food exports, to maintain stable export revenue. This explains why the food export effect on growth has become positive during the crisis period.

The overall results confirm the positive fuel export effect on the CEE economic growth after the EU accession. To a certain extent, the export specialization in major raw material exports, such as fuels, can boost growth (Naude, Bosker, and Matthee, 2010). Despite the ongoing shift toward manufactured exports, the CEE countries have maintained significant amounts of fuel exports to sustain their growth. Due to the different comparative advantages, most of the low-income CEE countries have still relied on raw material exports as their major exports (Zaghini, 2005). In particular, fuel exports have accelerated their growth since EU accession in 2004. The deep trade ties have consolidated western EU countries as the major markets for the CEE exports for decades (De Benedictis and Tajoli, 2007). Moreover, the EU has allowed the CEE countries to have greater access to the entire EU markets for their fuel exports. The adoption of the euro has further expanded their trade flows with other eurozone countries because of the elimination of exchange rate volatility (Mikaa and Zymekb, 2018). The drop in fuel export prices has further boosted their competitiveness in western EU countries. The steady gain in the market shares has contributed to the CEE economic growth since the EMU accession. Moreover, it is noteworthy that the fuel and food exports have continued to promote their growth despite the crisis outbreak in 2009-2016. There has been a sharp drop in the consumer demand for the CEE exports as a result of the 2010 eurozone debt crisis. Nonetheless, the demand for necessity exports, such as fuels and food, has remained high in western EU countries despite the onset of the crises. The rising prices and steady demand for raw material exports have helped sustain the CEE economic growth during the crisis period.

Contrary to expectations, agricultural exports have no impact on CEE growth at all. As presented in Tables 1, 2, 4, and 5, the coefficient on Agric is not statistically significant at all during the entire period 1999-2016. This may be attributed to the adoption of the EU Common Agricultural Policy for several decades. Due to food security reasons, western EU countries have allocated a large amount of funding to their local agricultural sectors to ensure a steady supply of food products. They have given income subsidies and investment funds to farmers to modernize their farming sectors. This has made it difficult for the CEE agricultural and food exports to gain market shares in western EU countries. This can explain why the CEE agricultural and food exports have no positive effect on their economic growth during the study period. Most importantly, the results highlight the importance for the CEE countries to boost their growth through export diversification toward manufactured exports. This would allow them to reduce their dependence on raw material exports. Furthermore, it would better insulate their export industries against economic shocks (Eicher and Kuenzel, 2016). In particular, this can mitigate the negative impact of price fluctuations in raw material exports on export growth (Naude, Bosker, and Matthee, 2010). Export diversification would enable the CEE countries to maintain high economic growth after they become middle-income countries.

Most of the manufactured exports, excepting machinery exports, have a positive effect on the CEE economic growth. Specifically, the transportation equipment exports consistently have positive growth effect before and after the EU accession. 
As noted in Table 1, the 2SLS coefficient on Transp is positive and statistically significant in 1999-2003 and 2004-2016, with the level of statistical significance increasing to the 5 percent level during the EU and crisis periods 2004-2016. In contrast, the textile and steel and chemical exports only have positive effects after the EU accession in 2004-2008. As shown in Tables 1, 3, 4, and 6, the 2SLS and GMM coefficients on Textil are all positive and highly significant in 2004-2008. As presented in Tables 1 and 3, the same results are found in the 2SLS coefficients on Steelchem during the same period. Moreover, the overall results suggest that the textile and steel and chemical exports have the larger growth-enhancing effect than the transportation equipment exports. As noted in Table 1, the size of the 2SLS coefficients on Textil and Steelchem is larger than that on Transp. However, the transportation equipment exports have positive growth effect before and after the EU accession.

The overall results indicate that manufactured exports, such as textile, transportation equipment, and steel and chemicals, have accelerated CEE growth after their EU accession. The CEE countries have enjoyed the economies of scale in production because of greater access to western EU markets. The shift toward manufactured exports has helped sustain the higher growth for the past decade (Kali, Mendez, and Reyes, 2007). Moreover, to maximize the benefits of strong export growth, they started to adopt a export diversification policy two decades ago. It has facilitated the risk diversification, which has reduced the possibility of adverse economic shocks in specific export sectors (Estevesa and Prades, 2018). In particular, this has stabilized the demand for the CEE manufactured exports in western EU countries. In sum, the export diversification policy has helped the CEE countries earn more export revenue despite the intense global competition. This has sustained their higher economic growth for the past decade. Another reason for the strong export-growth relationship is that the production of manufactured exports has resulted in the higher productivity and externality effects (Greenaway, Morgan, and Wright, 1999). The CEE companies have further improved their productivity levels through higher FDI and trade flows. The FDI inflows from western EU countries have facilitated the transfer of more efficient production methods to the CEE companies (Zaghini, 2005). They have adopted foreign production technology to improve the quality of differentiated manufactured exports. The resource allocations toward higher productivity export sectors have contributed to their higher economic growth (Naude, Bosker, and Matthee, 2010). Moreover, the production of manufactured goods has led to the higher externality effects, especially in high-technology manufactured exports. They have a higher potential for positive externalities, including the transfer of foreign knowledge and technology spillovers to the local companies through FDI. Meanwhile, the CEE countries have achieved better resource allocation and higher productivity in export industries rather than local industries due to the global competition factor (Cuaresma and Worz, 2005). Due to the EU membership, they have targeted western EU countries as the major export markets for their differentiated manufactured exports. The export diversification policy has accelerated their economic growth in the long run.

It is noteworthy that the similar export composition between the CEE and western EU countries has contributed to their higher income convergence. The CEE countries have adopted the export-oriented growth policy to accelerate their industrialization process since the early 1990s. The western EU countries have long served as the main export markets for the CEE manufactured exports. On average, they have imported 70 percent of the CEE exports for several decades. Their good export performance has been partly attributed to the implementation of western EU export policy. To boost their export competitiveness, CEE countries, such as the Czech Republic, Hungary, and Poland, have shifted their export emphasis toward high-quality manufactured exports. They have gained comparative advantages in manufactured exports through FDI and trade flows. 
Those countries that have similar export compositions with western EU countries have enjoyed higher income convergence since the 1990s (De Benedictis and Tajoli, 2008). The export-oriented growth policy with an emphasis on manufactured exports has helped reduce their substantial income gap with western EU countries (Huchet-Bourdon, Le Mouel, and Vijil, 2018). At the early stage of economic development, the CEE countries have continued to rely on raw material exports while diversifying high-quality manufactured exports. They have realized that the sole reliance on raw material exports has hindered their long-term economic growth (Dreger and Herzer, 2013). Based on their comparative advantages, they have allocated more resources toward high-quality manufactured goods (Naude and Rossouw, 2011). More research funding has facilitated the conversion of research innovation into commercial products. Given substantial improvement in product innovation, they have consolidated their market shares in western EU countries. This in turn has helped the CEE countries maintain sustainable high economic growth in the long run.

\section{Other Explanatory Variables Affecting the CEE Economic Growth}

Several explanatory variables are considered as conventional determinants of economic growth. First, the higher trade concentration has a positive effect on CEE growth during the crisis period. The estimation models in Tables 5 and 6 include the raw material and manufactured export variables, respectively. In both tables, the GMM coefficients on Tconcen are indeed positive and statistically significant in 2009-2016. This suggests that the trade concentration in the raw material and manufactured exports has promoted CEE growth after EU accession. The adoption of the euro has also boosted the intra-trade flows among the member countries during 2002-2013 (Mikaa and Zymekb, 2018). The CEE countries have expanded their market shares in the western EU countries as their differentiated manufactured exports have become more competitive in these markets (Kali, Mendez, and Reyes, 2007). It is interesting to note that the trade concentration effect became significant during the crisis period 2009-2016. This can be explained by the fact that western EU countries have remained the primary export markets for the CEE exports. While the CEE countries have tapped other non-EU countries as alternative export markets, they have still relied on the EU markets because of their EU membership. Therefore, the higher trade concentration variable has a positive effect on the CEE economic growth during 2009-2016.

A surprising result is the lack of foreign direct investment effect on the CEE economic growth. As showed in Tables 1 to 6, the 2SLS and GMM coefficients on FDI are not statistically significant for the entire period. This is contrary to the argument that FDI inflows would benefit domestic industries through technology transfer in developing countries. The positive externalities of FDI can help improve their technological capability and raise their productivity level. The export-oriented industries can further boost their export competitiveness, which in turn can boost their economic growth (Sohinger, 2005; Jouini, 2015). It follows that the FDI inflows, mostly from western EU countries, should have accelerated the CEE economic growth. However, the result of this study provides no support for this argument.

The current account has a negative effect on the CEE economic growth during 2004-2008, but it has a positive effect during 2004-2016. As presented in Tables 1 to 3, the 2SLS coefficients on Curact are negative and statistically significant in 2004-2008, but become positive in 2004-2016 and 2009-2016. The results are consistent with the argument that the current account variable has both a negative and positive effect on CEE growth. The increasing current account deficit diminished growth right after EU accession in 2004-2008. The CEE countries have increased their foreign borrowing from western EU countries to enhance their production activities. 
The current account deficit has incurred high financial burden on interest payment which has resulted in debt default (Cuestas, 2013). This lowered their economic growth during the early EU period 2004-2008. But the current account has a positive growth effect after this period. The EMU has deepened the CEE stock market and banking sector integration with western EU countries. Greater access to foreign capital has helped finance the CEE growing consumption and investment (Herrmann and Winkler, 2009). The larger current account deficit has sustained their high economic growth since 2009. This can explain why the current account deficit accelerated the CEE growth in 2009-2016.

Finally, public debt has either little or no effect on CEE economic growth during the entire period. As shown in Table 3, the only coefficient on Debt that is statistically significant and negative is found in 2004-2008, while the rest of the coefficients are not significant at all. The lack of the debt effect on growth is expected because of low public debt level among the CEE countries. In contrast to the eurozone crisis countries, such as Greece, Italy, and Spain, most of the CEE countries have maintained very low debt levels even before their EU accession. Their high economic growth performance has been partly attributed to low debt accumulation for decades (Gomez-Puig and Sosvilla-Rivero, 2015). When existing debt levels have been kept very low, the increase in debt for economic stimulus reasons has resulted in their higher economic growth (Baum, Checherita-Westphal, and Rother, 2013). The CEE countries have maintained very low debt levels despite their greater access to foreign capital. This can explain why the debt level has no impact on the CEE economic growth during the entire period.

\section{Policy Implications for the CEE Long-Term Economic Growth}

The results have provided very important policy implications on how to boost CEE economic growth through restructuring export policy. First, the results confirm that the raw material exports, such as fuel and food exports, have boosted CEE growth after the EU accession. Food exports have even become a crucial growth factor during the crisis period. In general, raw material exports, rather than manufactured exports, would lead to higher growth because the former have more stable prices than the latter during crisis periods (Grancay, Grancay, and Dudas, 2015). The demand for raw material exports would remain high as most of them are necessity products. The CEE countries should continue to emphasize production of raw materials for export. More resources should be allocated to this export sector, as it would earn stable amounts of export revenue (Dawson and Hubbard, 2004). In particular, the CEE countries should further improve production efficiency for fuel and food exports. To achieve this, the CEE countries should attract more foreign direct investments in raw material processing industries. The transfer of foreign production technologies would help the CEE companies to boost their fuel and food export competitiveness in western EU countries. In the long run, resource allocations toward more industrialized export sectors would accelerate economic growth in the CEE countries (Balaguer and Cantavella-Jorda, 2004). While the CEE countries gradually shift their export emphasis toward manufactured exports, they should also maintain raw material exports as part of their export-led growth policy.

Second, the results suggest that the manufactured exports (textile, transportation equipment, and steel and chemical) have a positive effect on the CEE economic growth both before and after EU accession. In particular, the textile and steel and chemical exports have larger growth effects than transportation equipment exports. The manufacturing export sectors in the CEE countries have developed rapidly after the EU accession. The massive FDI inflows from western EU countries have improved their product innovation in export industries. In particular, these inflows have upgraded the production facilities for manufacturing industries (Zaghini, 2005). The imports of advanced capital goods have facilitated the 
CEE companies to produce high value-added industrial exports. To some extent, the emphasis on importing capital goods for producing consumer goods has sustained their high economic growth (Lewer and Van den Berg, 2003). In the long run, they have to develop technology leadership to maintain their product competitiveness. Compared to western EU countries, the CEE countries have allocated a small amount of funding on research and innovation. The governments, rather than private companies, have primarily paid for the majority of these expenditures. This has slowed their progress in commercial product innovation. The CEE countries should plan industrial and trade policy to boost their technological progress in high-technology export industries. More resources should be allocated to efficient export sectors that can enhance economic growth (Cuaresma and Worz, 2005). The export-oriented countries, such as the Czech Republic, Poland, Hungary, and Slovenia, should concentrate on exporting manufactured goods with comparative advantages. Their main exports include automotive parts, electrical equipments and components, petroleum, and medicine. More research funding would boost their product innovation which, in turn, can consolidate their market shares in western EU countries. Access to these high-income consumer markets would be favorable to their long-term economic growth.

Third, the CEE countries should implement deeper financial market reforms to facilitate research funding. Although they have become more integrated with western EU countries after the EU integration, their stock markets have not been fully developed to receive the growing capital inflows. The foreign investor entry has accelerated their stock market expansion. Nonetheless, their stock markets have remained underdeveloped in terms of financial depth (Caporale et al., 2015). They have become partially integrated with some of the major foreign stock markets, such as the German and US stock markets. The financial crises since 2008 have slowed the CEE stock market development. To expand the stock market size, the CEE countries should undertake major stock market reforms to establish proper institutional and corporate governance framework. Better market regulatory and supervisory mechanisms would increase their appeal to eurozone stock markets. The continued stock market expansion would facilitate more foreign capital inflows for product innovation research. Moreover, the CEE banking sectors have been dominated by western EU banks through massive bank mergers and acquisitions since the 1990s. However, the increase in bank capital has not been allocated for productive investment, such as technological innovation (Ductor and Grechyna, 2015). The CEE countries should deepen their banking sector reforms. Better banking regulatory frameworks would improve banking supervision and access to foreign bank capitals. As western EU mergers and acquisitions have resulted in excessive bank concentration, new anti-trust legislations should be established to maintain high level of bank competition. This would diversify foreign bank entry from non-EU countries. The increase in bank credit flows would be better allocated for research and development projects. More developed stock markets and banking sectors would help finance product innovation projects in the CEE countries. This would allow them to maintain sustainable high economic growth in the long run.

\section{CONCLUSION}

This study examines whether export compositions have affected economic growth in the CEE countries during 1999-2016. First, the results confirm that major raw material exports have continued to play a crucial role in boosting CEE growth. Specifically, fuel exports have had a positive growth impact during the EU period 2004-2016. However, this effect has somewhat declined due to the outbreak of the US financial crisis and the eurozone debt crisis in 2009-2016. In contrast, food exports only have a positive growth effect during the crisis period 2009-2016. To offset the decline in the export demand, the 
CEE countries might have shifted their major resources toward necessity products, such as food exports, to maintain stable export revenues. This explains their positive growth effect during the crisis period. As expected, agricultural exports have no growth effect. This may be largely due to adopting the EU Common Agricultural Policy several decades ago. EU protectionist policies, such as farm subsidies and investment funds, have made it difficult for CEE farmers to gain market shares in these countries. Second, the results indicate that manufactured exports, such as transportation equipment, textile, steel, and chemical exports, have a positive growth effect before and after EU accession. The results also suggest that textile and steel and chemical exports have a larger growth effect than transportation equipment exports. The substantial growth effects can be attributed to the fact that the CEE countries have enjoyed the economies of scale in production. EU membership has led to their greater access to western EU markets.

Table 1: 2SLS Estimation of Export Composition Effects on CEE Economic Growth

\begin{tabular}{|c|c|c|c|c|c|}
\hline & (1) & (2) & (3) & (4) & (5) \\
\hline & 1999-2016 & 1999-2003 & 2004-2008 & $2009-2016$ & 2004-2016 \\
\hline \multirow[t]{2}{*}{ Curact } & $0.181^{\star * *}$ & 0.043 & $-0.528^{*}$ & $0.198^{\star * *}$ & $0.149^{* *}$ \\
\hline & $(2.790)$ & $(0.120)$ & $(-1.698)$ & $(2.459)$ & $(2.236)$ \\
\hline \multirow[t]{2}{*}{ Debt } & -0.079 & 1.233 & -0.702 & 0.458 & -0.191 \\
\hline & $(-0.311)$ & $(0.560)$ & $(-1.239)$ & $(0.804)$ & $(-0.632)$ \\
\hline \multirow[t]{2}{*}{ Tconcen } & 0.251 & -1.409 & 0.038 & 0.588 & 0.443 \\
\hline & $(0.728)$ & $(-0.234)$ & $(0.104)$ & $(0.610)$ & $(1.182)$ \\
\hline \multirow[t]{2}{*}{ FDI } & 0.245 & -0.537 & 0.072 & -0.065 & -0.002 \\
\hline & $(0.711)$ & $(-0.158)$ & $(0.114)$ & $(-0.312)$ & $(-0.008)$ \\
\hline \multirow[t]{2}{*}{ Popgrow } & $0.146^{\star}$ & 0.241 & 0.073 & 0.162 & 0.077 \\
\hline & $(1.853)$ & $(0.953)$ & $(0.613)$ & $(1.506)$ & $(0.958)$ \\
\hline \multirow[t]{2}{*}{ Capform } & 0.024 & 0.036 & $4.280^{\star \star \star}$ & -0.079 & 0.084 \\
\hline & $(0.027)$ & $(0.020)$ & $(2.473)$ & $(-0.077)$ & $(0.109)$ \\
\hline \multirow[t]{2}{*}{ School } & -0.116 & 3.117 & 7.164 & 1.444 & -0.737 \\
\hline & $(-0.083)$ & $(0.296)$ & $(1.173)$ & $(0.641)$ & $(-0.473)$ \\
\hline \multirow[t]{2}{*}{ Agric } & -0.441 & -2.055 & -0.978 & $-9.339^{* * *}$ & -1.190 \\
\hline & $(-0.853)$ & $(-1.036)$ & $(-0.376)$ & $(-2.662)$ & $(-1.218)$ \\
\hline \multirow[t]{2}{*}{ Food } & 0.216 & -0.855 & -0.289 & $8.573^{\star * *}$ & 0.382 \\
\hline & $(0.359)$ & $(-0.429)$ & $(-0.127)$ & $(2.624)$ & $(0.436)$ \\
\hline \multirow[t]{2}{*}{ Fuel } & $0.161^{\star \star \star}$ & 0.623 & 0.315 & $0.187^{\star}$ & $0.119^{\star}$ \\
\hline & $(2.359)$ & $(0.799)$ & $(1.546)$ & $(1.751)$ & $(1.662)$ \\
\hline \multirow[t]{2}{*}{ Mach } & -0.173 & 0.427 & -0.837 & -0.990 & -0.813 \\
\hline & $(-0.702)$ & $(0.347)$ & $(-1.241)$ & $(-1.280)$ & $(-1.574)$ \\
\hline \multirow[t]{2}{*}{ Textil } & 0.161 & 1.991 & $2.947^{\star \star *}$ & -0.369 & 0.204 \\
\hline & $(0.551)$ & $(0.471)$ & $(3.402)$ & $(-0.620)$ & $(0.558)$ \\
\hline \multirow[t]{2}{*}{ Transp } & 0.197 & $0.814^{\star}$ & 0.714 & $0.791^{\star}$ & $0.635^{\star *}$ \\
\hline & $(0.947)$ & $(1.748)$ & $(0.865)$ & $(1.701)$ & $(2.056)$ \\
\hline \multirow[t]{2}{*}{ SteelChem } & -0.004 & $-1.855^{\star}$ & $2.150^{\star * *}$ & -0.438 & 0.440 \\
\hline & $(-0.008)$ & $(-1.701)$ & $(2.656)$ & $(-0.739)$ & $(1.227)$ \\
\hline Adjusted $\mathrm{R}^{2}$ & 0.155 & 0.324 & 0.631 & 0.243 & 0.335 \\
\hline Observations & 234 & 65 & 65 & 104 & 169 \\
\hline
\end{tabular}

Notes: 2 SLS refers to the two-stage least squares estimation.

All variables are in logarithm. $T$-statistics are reported in parentheses.

$* * *, * *, *$ indicate significance at $1 \%, 5 \%$, and $10 \%$. 
Table 2: 2SLS Estimation of Export Composition Effects on CEE Economic Growth (Raw Material Exports Only)

\begin{tabular}{|c|c|c|c|c|c|}
\hline & (1) & (2) & (3) & (4) & (5) \\
\hline & $1999-2016$ & 1999-2003 & 2004-2008 & 2009-2016 & 2004-2016 \\
\hline \multirow[t]{2}{*}{ Curact } & $0.196^{* * *}$ & -0.089 & -0.613 & $0.205^{\star * *}$ & $0.189^{* * *}$ \\
\hline & $(2.989)$ & $(-0.219)$ & $(-0.711)$ & $(2.497)$ & $(2.130)$ \\
\hline \multirow[t]{2}{*}{ Debt } & -0.112 & 0.560 & -0.641 & 0.220 & -0.298 \\
\hline & $(-0.471)$ & $(0.282)$ & $(-0.861)$ & $(0.386)$ & $(-1.030)$ \\
\hline \multirow[t]{2}{*}{ Tconcen } & 0.287 & 0.668 & 0.163 & $1.303^{*}$ & 0.508 \\
\hline & $(0.901)$ & $(0.174)$ & $(0.367)$ & $(1.748)$ & $(1.428)$ \\
\hline \multirow[t]{2}{*}{ FDI } & 0.126 & -1.344 & 0.506 & -0.105 & -0.065 \\
\hline & $(0.416)$ & $(-0.521)$ & $(0.294)$ & $(-0.461)$ & $(-0.079)$ \\
\hline \multirow[t]{2}{*}{ Popgrow } & $0.142^{\star *}$ & 0.359 & 0.046 & 0.132 & 0.067 \\
\hline & $(2.057)$ & $(1.151)$ & $(0.228)$ & $(1.254)$ & $(0.848)$ \\
\hline \multirow[t]{2}{*}{ Capform } & 0.187 & 1.193 & 2.029 & -0.342 & 0.057 \\
\hline & $(0.266)$ & $(0.435)$ & $(1.053)$ & $(-0.357)$ & $(0.077)$ \\
\hline \multirow[t]{2}{*}{ School } & -0.152 & 5.743 & -4.214 & -0.131 & -1.894 \\
\hline & $(-0.123)$ & $(0.423)$ & $(-0.592)$ & $(-0.069)$ & $(-1.280)$ \\
\hline \multirow[t]{2}{*}{ Agric } & -0.361 & 1.454 & 0.840 & $-9.041^{* * *}$ & -0.439 \\
\hline & $(-0.766)$ & $(0.632)$ & $(0.325)$ & $(-2.814)$ & $(-0.506)$ \\
\hline \multirow[t]{2}{*}{ Food } & 0.149 & -1.916 & -1.436 & $8.343^{\star * *}$ & 0.004 \\
\hline & $(0.320)$ & $(-0.830)$ & $(-1.134)$ & $(2.769)$ & $(0.004)$ \\
\hline \multirow[t]{2}{*}{ Fuel } & $0.158^{\star * *}$ & 0.752 & -0.092 & 0.145 & $0.124^{\star \star}$ \\
\hline & $(2.584)$ & $(1.230)$ & $(-0.287)$ & $(1.330)$ & $(2.012)$ \\
\hline Adjusted $\mathrm{R}^{2}$ & 0.212 & 0.066 & 0.329 & 0.223 & 0.322 \\
\hline Observations & 234 & 65 & 65 & 104 & 169 \\
\hline
\end{tabular}

Notes: 2SLS refers to the two-stage least squares estimation.

All variables are in logarithm. T-statistics are reported in parentheses.

$* * *, * *, *$ indicate significance at $1 \%, 5 \%$, and $10 \%$. 
Table 3: 2SLS Estimation of Export Composition Effects on CEE Economic Growth (Manufactured Exports Only)

\begin{tabular}{|c|c|c|c|c|c|}
\hline & $(1)$ & $(2)$ & (3) & (4) & (5) \\
\hline & 1999-2016 & 1999-2003 & 2004-2008 & 2009-2016 & 2004-2016 \\
\hline \multirow[t]{2}{*}{ Curact } & $0.173^{\star * *}$ & 0.222 & $-0.653^{* * *}$ & $0.152^{\star *}$ & $0.165^{\star * *}$ \\
\hline & $(2.404)$ & $(0.723)$ & $(-2.426)$ & $(1.876)$ & $(2.552)$ \\
\hline \multirow[t]{2}{*}{ Debt } & -0.037 & -0.097 & $-1.180^{\star *}$ & 0.038 & -0.281 \\
\hline & $(-0.139)$ & $(-0.064)$ & $(-2.214)$ & $(0.069)$ & $(-0.984)$ \\
\hline \multirow[t]{2}{*}{ Tconcen } & 0.375 & 2.677 & 0.330 & 1.164 & 0.490 \\
\hline & $(1.168)$ & $(0.895)$ & $(0.960)$ & (1.194) & $(1.287)$ \\
\hline \multirow[t]{2}{*}{ FDI } & 0.255 & 1.127 & 0.018 & -0.045 & 0.072 \\
\hline & $(0.758)$ & $(0.487)$ & $(0.039)$ & $(-0.209)$ & $(0.313)$ \\
\hline \multirow[t]{2}{*}{ Popgrow } & $0.150^{*}$ & 0.140 & 0.020 & 0.149 & 0.075 \\
\hline & $(1.843)$ & $(0.679)$ & $(0.180)$ & $(1.307)$ & $(0.903)$ \\
\hline \multirow[t]{2}{*}{ Capform } & 0.282 & 1.116 & $3.129^{\star *}$ & 0.805 & 0.072 \\
\hline & $(0.371)$ & $(0.478)$ & $(2.258)$ & $(0.777)$ & $(0.099)$ \\
\hline \multirow[t]{2}{*}{ School } & -0.313 & 9.003 & 5.242 & -0.697 & -2.270 \\
\hline & $(-0.244)$ & $(0.959)$ & $(1.055)$ & $(-0.318)$ & $(-1.549)$ \\
\hline \multirow[t]{2}{*}{ Mach } & -0.177 & 1.068 & $-1.103^{*}$ & -0.457 & -0.780 \\
\hline & $(-0.716)$ & $(1.046)$ & $(-1.769)$ & $(-0.584)$ & $(-1.531)$ \\
\hline \multirow[t]{2}{*}{ Textil } & -0.014 & -1.049 & $2.332^{* * *}$ & -0.274 & -0.026 \\
\hline & $(-0.059)$ & $(-0.517)$ & $(4.592)$ & $(-0.440)$ & $(-0.077)$ \\
\hline \multirow[t]{2}{*}{ Transp } & 0.170 & 0.327 & $(1.366)$ & 0.529 & 0.455 \\
\hline & $(0.913)$ & $(0.608)$ & $1.905^{\star * *}$ & $(1.121)$ & $(1.435)$ \\
\hline \multirow[t]{2}{*}{ SteelChem } & 0.095 & -1.298 & $1.905^{\star * *}$ & -0.768 & 0.245 \\
\hline & $(0.295)$ & $(-0.692)$ & $(2.537)$ & $(-1.489)$ & $(0.796)$ \\
\hline Adjusted $\mathrm{R}^{2}$ & 0.132 & 0.330 & 0.608 & 0.162 & 0.308 \\
\hline Observations & 234 & 65 & 65 & 104 & 169 \\
\hline
\end{tabular}

Notes: 2SLS refers to the two-stage least squares estimation.

All variables are in logarithm. T-statistics are reported in parentheses.

$* * *, * *, *$ indicate significance at $1 \%, 5 \%$, and $10 \%$. 
Table 4: GMM Estimation of Export Composition Effects on CEE Economic Growth

\begin{tabular}{|c|c|c|c|c|c|}
\hline & $(1)$ & $(2)$ & (3) & (4) & $(5)$ \\
\hline & 1999-2016 & 1999-2003 & 2004-2008 & 2009-2016 & 2004-2016 \\
\hline \multirow[t]{2}{*}{ Curact } & $0.156^{\star *}$ & 0.031 & 0.130 & 0.127 & $0.148^{\star}$ \\
\hline & $(1.950)$ & $(0.064)$ & $(0.259)$ & $(1.260)$ & (1.787) \\
\hline \multirow[t]{2}{*}{ Debt } & -0.263 & -1.239 & -1.506 & 0.445 & 0.046 \\
\hline & $(-0.572)$ & $(-0.481)$ & $(-0.101)$ & $(0.659)$ & $(0.093)$ \\
\hline \multirow[t]{2}{*}{ Tconcen } & 0.441 & 2.306 & 0.020 & 1.556 & 0.423 \\
\hline & $(1.702)$ & $(0.555)$ & $(0.038)$ & $(1.547)$ & $(1.041)$ \\
\hline \multirow[t]{2}{*}{ FDI } & -0.065 & 2.873 & -0.674 & -0.061 & -0.209 \\
\hline & $(-0.216)$ & $(0.944)$ & $(-0.450)$ & $(-0.210)$ & $(-0.809)$ \\
\hline \multirow[t]{2}{*}{ Popgrow } & $0.203^{* * *}$ & 0.072 & 0.122 & 0.167 & $0.163^{*}$ \\
\hline & $(2.560)$ & $(0.202)$ & $(0.611)$ & (1.407) & (1.713) \\
\hline \multirow[t]{2}{*}{ Capform } & 0.501 & 2.012 & 1.989 & 0.427 & 1.148 \\
\hline & $(0.531)$ & $(0.513)$ & $(0.998)$ & $(0.309)$ & $(1.153)$ \\
\hline \multirow[t]{2}{*}{ School } & -1.945 & 14.149 & 0.256 & -0.813 & $-3.648^{\star}$ \\
\hline & $(-0.973)$ & $(0.959)$ & $(0.042)$ & $(-0.246)$ & $(-1.684)$ \\
\hline \multirow[t]{2}{*}{ Agric } & -0.677 & 0.793 & 0.776 & $-10.232^{\star *}$ & -0.732 \\
\hline & $(-0.663)$ & $(0.185)$ & $(0.427)$ & $(-2.035)$ & $(-0.499)$ \\
\hline \multirow[t]{2}{*}{ Food } & 0.192 & 0.015 & -0.845 & $9.220^{* *}$ & 0.537 \\
\hline & $(0.233)$ & $(0.006)$ & $(-0.705)$ & $(1.979)$ & $(0.429)$ \\
\hline \multirow[t]{2}{*}{ Fuel } & $0.291^{\star * *}$ & 0.038 & -0.060 & 0.162 & $0.218^{\star \star}$ \\
\hline & $(2.859)$ & $(0.061)$ & $(-0.168)$ & $(1.228)$ & $(1.985)$ \\
\hline \multirow[t]{2}{*}{ Mach } & -0.029 & -0.358 & 0.610 & -0.069 & -0.545 \\
\hline & $(-0.071)$ & $(-0.178)$ & $(0.704)$ & $(-0.073)$ & $(-1.047)$ \\
\hline \multirow[t]{2}{*}{ Textil } & 0.115 & -2.548 & $2.227^{\star * *}$ & -0.639 & 0.045 \\
\hline & $(0.215)$ & $(-0.632)$ & $(2.594)$ & $(-0.650)$ & $(0.076)$ \\
\hline \multirow[t]{2}{*}{ Transp } & 0.276 & 0.617 & -0.111 & -0.013 & 0.285 \\
\hline & $(1.044)$ & $(0.599)$ & $(0.173)$ & $(-0.022)$ & $(0.788)$ \\
\hline \multirow[t]{2}{*}{ SteelChem } & -0.653 & -1.237 & 2.759 & -0.591 & -0.657 \\
\hline & $(-1.311)$ & $(-0.466)$ & $(0.940)$ & $(-0.945)$ & $(-1.348)$ \\
\hline J-Statistic & 0.277 & 0.053 & 5.138 & 1.357 & 0.218 \\
\hline AR(1) Test & -3.969 & -0.982 & -1.394 & -2.264 & -3.611 \\
\hline (p-value) & $(0.001)$ & $(0.326)$ & $(0.163)$ & $(0.024)$ & $(0.003)$ \\
\hline AR(2) Test & 0.332 & -0.619 & 1.021 & 0.015 & 0.845 \\
\hline (p-value) & $(0.740)$ & $(0.535)$ & $(0.307)$ & $(0.988)$ & $(0.398)$ \\
\hline Observations & 234 & 65 & 65 & 104 & 169 \\
\hline
\end{tabular}

Notes: GMM refers to the dynamic generalized method of moments estimation.

All variables are in logarithm. T-statistics are reported in parentheses.

$* * *, * *, *$ indicate significance at $1 \%, 5 \%$, and $10 \%$. 
Table 5: GMM Estimation of Export Composition Effects on CEE Economic Growth (Raw Material Exports Only)

\begin{tabular}{|c|c|c|c|c|c|}
\hline & (1) & $(2)$ & (3) & (4) & (5) \\
\hline & $1999-2016$ & 1999-2003 & 2004-2008 & 2009-2016 & 2004-2016 \\
\hline \multirow[t]{2}{*}{ Curact } & $0.152^{\star *}$ & 0.010 & 0.628 & 0.118 & 0.126 \\
\hline & $(1.935)$ & $(0.013)$ & $(1.382)$ & (1.183) & $(1.554)$ \\
\hline \multirow[t]{2}{*}{ Debt } & -0.383 & -0.650 & -1.241 & 0.578 & 0.003 \\
\hline & $(-0.875)$ & $(-0.144)$ & $(-1.101)$ & $(0.858)$ & $(0.006)$ \\
\hline \multirow[t]{2}{*}{ Tconcen } & 0.522 & 3.374 & 0.355 & $1.712^{\star \star}$ & 0.509 \\
\hline & $(1.291)$ & $(0.539)$ & $(0.502)$ & (1.958) & (1.258) \\
\hline \multirow[t]{2}{*}{ FDI } & -0.091 & 4.760 & -1.300 & -0.085 & -0.271 \\
\hline & $(-0.357)$ & $(0.609)$ & $(-1.557)$ & $(-0.319)$ & $(-1.221)$ \\
\hline \multirow[t]{2}{*}{ Popgrow } & $0.197^{\star * *}$ & -0.112 & 0.216 & 0.157 & $0.157^{\star}$ \\
\hline & $(2.544)$ & $(-0.147)$ & $(0.966)$ & $(1.365)$ & $(1.684)$ \\
\hline \multirow[t]{2}{*}{ Capform } & 0.330 & -0.662 & 0.500 & 0.423 & 1.269 \\
\hline & $(0.361)$ & $(-0.107)$ & $(0.234)$ & $(0.319)$ & $(1.322)$ \\
\hline \multirow[t]{2}{*}{ School } & -1.660 & 24.590 & -1.963 & -0.404 & -3.168 \\
\hline & $(-0.868)$ & $(0.811)$ & $(-0.398)$ & $(-0.129)$ & $(-1.493)$ \\
\hline \multirow[t]{2}{*}{ Agric } & -0.481 & -0.056 & 3.032 & $-12.015^{\star \star *}$ & -0.800 \\
\hline & $(-0.463)$ & $(-0.011)$ & $(1.461)$ & $(-2.404)$ & $(-0.532)$ \\
\hline \multirow[t]{2}{*}{ Food } & 0.210 & 1.036 & -0.955 & $10.475^{\star *}$ & 0.313 \\
\hline & $(0.247)$ & $(0.214)$ & $(-0.636)$ & $(2.270)$ & $(0.259)$ \\
\hline \multirow[t]{2}{*}{ Fuel } & $0.274^{\star * *}$ & -0.239 & -0.201 & $0.195^{\star}$ & $0.215^{\star * *}$ \\
\hline & $(3.147)$ & $(-0.167)$ & $(-0.848)$ & $(1.780)$ & $(2.401)$ \\
\hline J-Statistic & 0.127 & 0.001 & 0.061 & 0.749 & 0.444 \\
\hline $\mathrm{AR}(1)$ Test & -4.325 & -0.607 & -1.013 & -2.478 & -4.046 \\
\hline (p-value) & $(0.001)$ & $(0.544)$ & $(0.311)$ & $(0.013)$ & $(0.001)$ \\
\hline $\operatorname{AR}(2)$ Test & 0.308 & -0.318 & 0.939 & 0.161 & 0.934 \\
\hline (p-value) & $(0.758)$ & $(0.750)$ & $(0.348)$ & $(0.872)$ & $(0.350)$ \\
\hline Observations & 234 & 65 & 65 & 104 & 169 \\
\hline
\end{tabular}

Notes: GMM refers to the dynamic generalized method of moments estimation.

All variables are in logarithm. T-statistics are reported in parentheses.

$* * *, * *, *$ indicate significance at $1 \%, 5 \%$, and $10 \%$. 
Table 6: GMM Estimation of Export Composition Effects on CEE Economic Growth (Manufactured Exports Only)

\begin{tabular}{|c|c|c|c|c|c|}
\hline & (1) & (2) & (3) & (4) & (5) \\
\hline & $1999-2016$ & 1999-2003 & 2004-2008 & 2009-2016 & 2004-2016 \\
\hline \multirow[t]{2}{*}{ Curact } & $0.149^{*}$ & -0.003 & 0.154 & 0.129 & 0.136 \\
\hline & $(1.804)$ & $(-0.005)$ & $(0.355)$ & $(1.229)$ & $(1.580)$ \\
\hline \multirow[t]{2}{*}{ Debt } & -0.149 & -1.051 & -1.569 & 0.529 & 0.192 \\
\hline & $(-0.328)$ & $(-0.431)$ & $(-1.408)$ & $(0.843)$ & $(0.405)$ \\
\hline \multirow[t]{2}{*}{ Tconcen } & $0.729^{*}$ & 2.251 & 0.045 & $1.767^{\star}$ & 0.569 \\
\hline & $(1.681)$ & $(0.643)$ & $(0.111)$ & $(1.686)$ & $(1.366)$ \\
\hline \multirow[t]{2}{*}{ FDI } & -0.028 & 3.063 & -0.714 & -0.058 & -0.159 \\
\hline & $(-0.094)$ & $(0.975)$ & $(-0.601)$ & $(-0.215)$ & $(-0.629)$ \\
\hline \multirow[t]{2}{*}{ Popgrow } & $0.207^{\star * *}$ & 0.052 & 0.129 & 0.191 & $0.171^{\star}$ \\
\hline & $(2.515)$ & $(0.144)$ & $(0.698)$ & $(1.563)$ & (1.774) \\
\hline \multirow[t]{2}{*}{ Capform } & 0.895 & 2.237 & 1.859 & 1.216 & 1.455 \\
\hline & $(0.879)$ & $(0.541)$ & $(1.204)$ & $(0.877)$ & $(1.373)$ \\
\hline \multirow[t]{2}{*}{ School } & -3.180 & 14.478 & -0.199 & -3.739 & $-4.442^{\star *}$ \\
\hline & $(-1.561)$ & $(0.980)$ & $(-0.036)$ & $(-1.191)$ & $(-2.070)$ \\
\hline \multirow[t]{2}{*}{ Mach } & -0.046 & -0.329 & 0.405 & -0.060 & -0.452 \\
\hline & $(-0.109)$ & $(-0.159)$ & $(0.434)$ & $(-0.063)$ & $(-0.884)$ \\
\hline \multirow[t]{2}{*}{ Textil } & -0.557 & -2.314 & $2.454^{\star *}$ & -1.282 & -0.583 \\
\hline & $(-1.226)$ & $(-0.872)$ & $(2.341)$ & $(-1.421)$ & $(-1.189)$ \\
\hline \multirow[t]{2}{*}{ Transp } & 0.230 & 0.853 & -0.021 & -0.227 & 0.131 \\
\hline & $(0.905)$ & $(0.980)$ & $(-0.031)$ & $(-0.394)$ & $(0.389)$ \\
\hline \multirow[t]{2}{*}{ SteelChem } & -0.597 & -1.186 & 2.730 & -0.956 & -0.575 \\
\hline & $(-1.165)$ & $(-0.443)$ & $(1.192)$ & $(-1.572)$ & $(-1.128)$ \\
\hline J-Statistic & 0.118 & 0.031 & 5.212 & 0.850 & 0.497 \\
\hline AR(1) Test & -4.547 & -1.076 & -1.271 & -2.601 & -3.969 \\
\hline (p-value) & $(0.001)$ & $(0.282)$ & $(0.204)$ & $(0.009)$ & $(0.001)$ \\
\hline AR(2) Test & 0.141 & -0.566 & 1.025 & 0.014 & 0.738 \\
\hline (p-value) & $(0.888)$ & $(0.571)$ & $(0.305)$ & $(0.989)$ & $(0.460)$ \\
\hline Observations & 234 & 65 & 65 & 104 & 169 \\
\hline
\end{tabular}

Notes: GMM refers to the dynamic generalized method of moments estimation.

All variables are in logarithm. T-statistics are reported in parentheses.

$* * *, * *, *$ indicate significance at $1 \%, 5 \%$, and $10 \%$. 
Table 7: Summary Statistics

\begin{tabular}{|c|c|c|c|c|c|c|}
\hline Variable & Observation & Mean & Median & $\begin{array}{l}\text { Standard } \\
\text { Deviation }\end{array}$ & Maximum & Minimum \\
\hline GDP growth & 234 & 0.526 & 0.583 & 0.371 & 1.163 & -1.068 \\
\hline Current account & 234 & 2.517 & 2.637 & 0.461 & 3.407 & 1.058 \\
\hline Debt & 234 & 3.531 & 3.592 & 0.309 & 4.033 & 2.566 \\
\hline Trade concentration & 234 & 0.908 & 0.896 & 0.144 & 1.474 & 0.614 \\
\hline FDI & 234 & 2.689 & 2.665 & 0.841 & 4.655 & 0.682 \\
\hline Population growth & 234 & 1.528 & 1.691 & 0.573 & 0.455 & -1.621 \\
\hline Capital formation & 234 & 3.362 & 3.357 & 0.082 & 3.594 & 3.068 \\
\hline School enrollment & 234 & 3.989 & 3.991 & 0.031 & 4.077 & 3.894 \\
\hline Agricultural export & 234 & 2.614 & 2.625 & 0.286 & 3.179 & 2.019 \\
\hline Food export & 234 & 2.483 & 2.527 & 0.273 & 3.110 & 1.917 \\
\hline Fuel export & 234 & 2.293 & 2.326 & 0.543 & 3.232 & -1.658 \\
\hline Machinery export & 234 & 3.067 & 3.127 & 0.433 & 3.721 & 1.572 \\
\hline Textile export & 234 & 2.276 & 2.358 & 0.435 & 2.918 & 0.660 \\
\hline $\begin{array}{l}\text { Transportation } \\
\text { equipment export }\end{array}$ & 234 & 2.740 & 2.789 & 0.581 & 3.721 & 1.014 \\
\hline $\begin{array}{l}\text { Steel and chemical } \\
\text { export }\end{array}$ & 234 & 2.620 & 2.657 & 0.286 & 3.171 & 1.823 \\
\hline $\begin{array}{l}\text { Research and } \\
\text { development }\end{array}$ & 234 & 1.867 & 1.863 & 0.228 & 2.416 & 1.334 \\
\hline Inflation & 234 & 2.241 & 2.455 & 0.815 & 3.694 & 0.001 \\
\hline
\end{tabular}

\section{REFERENCES}

Balaguer, J., \& Cantavella-Jorda, M. (2004). Structural change in exports and economic growth: Cointegration and causality analysis for Spain 1961-2000. Applied Economics, 6(5), 473-477. https://doi.org/10.1080/00036840410001682179

Baum, A., Checherita-Westphal, C., \& Rother, P. (2013). Debt and growth: New evidence for the Euro area. Journal of International Money and Finance, 32, 809-821. https://doi.org/10.1016/j.jimonfin.2012.07.004

Cadot, O., Carrere, C., \& Strauss-Kahn, V. (2011). Export diversification: What's behind the hump? Review of Economics and Statistics, 93(2), 590-605. https://doi.org/10.1162/REST a 00078

Caporale, G. M., Rault, C., Sova, A. D., \& Sova, R. (2015). Financial development and economic growth: Evidence from 10 new European Union members. International Journal of Finance and Economics, 20(1), 48-60. https://doi.org/10.1002/ijfe.1498

Checherita-Westphal, C., \& Rother, P. (2012). The impact of high government debt on economic growth and its channels: An empirical investigation for the Euro area. European Economic Review, 56(7), 1392-1405. https://doi.org/10.1016/j.euroecorev.2012.06.007

Cuaresma, J. C., \& Worz, J. (2005). On export composition and growth. Review of World Economics, 141(1), 33-49. https://doi.org/10.1007/s10290-005-0014-Z

Cuestas, J. C. (2013). The current account sustainability of European transition economies. Journal of Common Market Studies, 51(2), 232-245. https://doi.org/10.1111/j.1468-5965.2012.02309.x

Dawson, P. J., \& Hubbard, L. J. (2004). Exports and economic growth in Central and East European countries during transition. Applied Economics, 36(16), 1819-1824.https://doi.org/10.1080/000368042000241123 
De Benedictis, L., \& Tajoli, L. (2007). Economic integration and similarity in trade structures. Empirica, 34(2), 117-137. https://doi.org/10.1007/s10663-006-9024-x

De Benedictis, L., \& Tajoli, L. (2007b). Openness, similarity in export composition, and income dynamics. Journal of International Trade and Economic Development, 16(1), 93-116. https://doi.org/10.1080/09638190601165798

De Benedictis, L., \& Tajoli, L. (2008). Similarity in trade structures, integration and catching-up. Economics of Transition, 16(2), 165-182. https://doi.org/10.1111/j.1468-0351.2008.00313.x

De Boyrie, M. E., \& Johns, R. (2013). The effects of trade agreements on the growth of major Latin American economies. Journal of International Trade and Economic Development, 22(3), 377-397. https://doi.org/10.1080/09638199.2011.578753

Dort, T., Meon, P. G., \& Sekkat, K. (2014). Does investment spur growth everywhere? Not where institutions are weak. Kyklos, 67(4), 482-505. https://doi.org/10.1111/kykl.12064

Dreger, C., \& Herzer, D. (2013). A further examination of the export-led growth hypothesis. Empirical Economics, 45(1), 39-60. https://doi.org/10.1007/s00181-012-0602-4

Ductor, L., \& Grechyna, D. (2015). Financial development, real sector, and economic growth. International Review of Economics and Finance, 37, 393-405. https://doi.org/10.1016/j.iref.2015.01.001

Eberhardta, M., \& Presbiteroc, A. F. (2015). Public debt and growth: Heterogeneity and non-linearity. Journal of International Economics, 97(1), 45-58. https://doi.org/10.1016/j.jinteco.2015.04.005

Eicher, T. S., \& Kuenzel, D. J. (2016). The elusive effects of trade on growth: Export diversity and economic take-off. Canadian Journal of Economics, 49(1), 264-295. https://doi.org/10.1111/caje.12197

Estevesa, P. S., \& Prades, E. (2018). Does export concentration matter in economic adjustment programs? Evidence from the Euro area. Journal of Policy Modeling, 40(2), 225-241.https://doi.org/10.1016/j.jpolmod.2017.10.005

European Commission. (2019). European Union countries and the Euro. Available at https://ec.europa.eu/info/ business-economy-euro/euro-area/euro/eu-countries-and-euro_en. (accessed November 26, 2019).

Gomez-Puig, M., \& Sosvilla-Rivero, S. (2015). The causal relationship between debt and growth in EMU countries. Journal of Policy Modeling, 37(6), 974-989. https://doi.org/10.1016/j.jpolmod.2015.09.004

Gozgor, G., \& Can, M. (2017). Causal linkages among the product diversification of exports, economic globalization and economic growth. Review of Development Economics, 21(3), 888-908. https://doi.org/10.1111/rode.12301

Grancay, M., Grancay, N., \& Dudas, T. (2015). What you export matters: Does it really? Contemporary Economics, 9(2), 233-244. https://doi.org/10.5709/ce.1897-9254.169

Greenaway, D., Morgan, W., \& Wright, P. (1999). Exports, export composition and growth. Journal of International Trade and Economic Development, 8(1), 41-51. https://doi.org/10.1080/09638199900000004

Hausmann, R., Hwang, J., \& Rodrik, D. (2007). What you export matters. Journal of Economic Growth, 12(1), 1-25. https://doi.org/10.1007/s10887-006-9009-4

Herrmann, S., \& Winkler, A. (2009). Financial markets and the current account: Emerging Europe versus emerging Asia. Review of World Economics/Weltwirtschaftliches Archiv, 145(3), 531-550. https://doi.org/10.1007/s10290-009-0025-2

Hubert, F., \& Pain, N. (2002). Fiscal incentives, European integration, and the location of foreign direct investment. The Manchester School, 70(3), 336-363. https://doi.org/10.1111/1467-9957.00306

Huchet-Bourdon, M., Le Mouel, C., \& Vijil, M. (2018). The relationship between trade openness and economic growth: Some new insights on the openness measurement issue. World Economy, 41(1), 59-76. https://doi.org/10.1111/twec.12586

Jagelka, T. (2013). Bilateral trade and the Eurozone: Evidence from new member countries. World Economy, 36(1), 48-63. https://doi.org/10.1111/twec.12013

Jouini, J. (2015). Linkage between international trade and economic growth in GCC countries: Empirical evidence from PMG estimation approach. Journal of International Trade and Economic Development, 24(3), 341-372. https://doi.org/10.1080/09638199.2014.904394

Kali, R., Mendez, F., \& Reyes, J. (2007). Trade structure and economic growth. Journal of International Trade and Economic Development, 16(2), 245-269. https://doi.org/10.1080/09638190701325649 
Lewer, J. J., \& Van den Berg, H. (2003). Does trade composition influence economic growth? Time series evidence for 28 OECD and developing countries. Journal of International Trade and Economic Development, 12(1), 39-96. https://doi.org/10.1080/0963819032000049150

Mikaa, A., \& Zymekb, R. (2018). Friends without benefits? New EMU members and the Euro effect on trade. Journal of International Money and Finance, 83, 75-92. https://doi.org/10.1016/j.jimonfin.2018.02.001

Murshed, S. M., \& Serino, L. A. (2011). The pattern of specialization and economic growth: The resource curse hypothesis revisited. Structural Change and Economic Dynamics, 22(2), 151-161. https://doi.org/10.1016/j.strueco.2010.12.004

Naude, W., Bosker, M., \& Matthee, M. (2010). Export specialisation and local economic growth. World Economy, 33(4), 552-572. https://doi.org/10.1111/j.1467-9701.2009.01239.x

Naude, W., \& Rossouw, R. (2011). Export diversification and economic performance: Evidence from Brazil, China, India and South Africa. Economic Change and Restructuring, 44(1-2), 99-134. https://doi.org/10.1007/ s10644-010-9089-1

Poncet, S., \& De Waldemar, F. S. (2013). Export upgrading and growth: The prerequisite of domestic embeddedness. World Development, 51, 104-118. https://doi.org/10.1016/j.worlddev.2013.05.010

Slavov, S. T. (2009). Do common currencies facilitate the net flow of capital among countries? North American Journal of Economics and Finance, 20(2), 124-144. https://doi.org/10.1016/j.najef.2009.03.003

Sohinger, J. (2005). Growth and convergence in European transition economies: The impact of foreign direct investment. Eastern European Economics, 43(2), 73-94. https://doi.org/10.1080/00128775.2005.11041099

Sterlacchini, A. (2008). R\&D, higher education and regional growth: Uneven linkages among European regions. Research Policy, 37(6/7), 1096-1107. https://doi.org/10.1016/j.respol.2008.04.009

Tang, D. (2019). Have export compositions influenced the economic growth among the European Union countries in Central and Eastern Europe? Mendeley Data, https://data.mendeley.com/datasets/6v3zchvc57/1

Wierts, P., Van Kerkhoff, H., \& De Haan, J. (2014). Composition of exports and export performance of Eurozone countries. Journal of Common Market Studies, 52(4), 928-941. https://doi.org/10.1111/jcms.12114

Zaghini, A. (2005). Evolution of trade patterns in the new EU member states. Economics of Transition, 13(4), 629-658. https://doi.org/10.1111/j.0967-0750.2005.00235.x 
DA LI JE STRUKTURA IZVOZA UTICALA NA EKONOMSKI RAST ZEMALJA EVROPSKE UNIJE U CENTRALNOJ I ISTOČNOJ EVROPI?

\section{Rezime:}

Ova studija analizira uticaj izvoza na ekonomski rast od 1999. do 2016. godine u zemljama centralne i istočne Evrope koje su članice Evropske unije. Rezultati potvrđuju da je izvoz goriva i hrane podstakao rast nakon pridruživanja Evropskoj Uniji. Kao što se očekivalo, izvoz poljoprivrednih proizvoda nema uticaja na rast. Zbog različitih komparativnih prednosti, zemlje centralne i istočne Evrope su se još uvek oslanjale na izvoz nekih sirovina dok su radile na povećanju izvoza gotovih proizvoda. Rezultati takođe pokazuju da je izvoz transportne opreme, tekstila, čelika i hemijskih proizvoda ubrzao rast. To se može pripisati obimu proizvodnje s obzirom na pristup mnogo većem tržištu u okviru Evropske Unije.
Ključne reči:

struktura izvoza, ekonomski rast, ekonomska integracija. 